\title{
Assessment of Land Use/Land Cover Changes in Coimbatore North Taluk, Tamil Nadu, India using GIS and Remote Sensing
}

\author{
M. Ganeshmoorthi ${ }^{1}$ and S.R. Nagarathinam ${ }^{2}$ \\ ${ }^{1}$ Research Scholar, ${ }^{2}$ Associate Professor and Head (Rtd...) \\ PG \& Research Department of Geography, Government Arts College (Autonomous), Coimbatore, Tamil Nadu, India \\ E-Mail: gm.moorthi@gmail.com
}

\begin{abstract}
The main aim of the present study is to assess Land use/land cover changes in Coimbatore North Taluk for the period of 2001 and 2018. The study area is located in Coimbatore district, Tamil Nadu state and geographical area is $479.5 \mathrm{~km} 2$. To analyze land use/land cover changes, a temporal satellite images Landsat 7 (2001) Sentinel-2 (2018) was used. Vector data for the study area was extracted from the SOI toposheets and taluk sheets. The above satellite image was classified into four major classes viz. water bodies, croplands, built-up area, and forest using hybrid supervised classification method. ERDAS Imagine 2015 and ArcGIS 10.5 software's were sued to classify the satellite image and assess the land use/land cover changes for the above periods. The land use/land cover change detection analysis revealed that built up area was increased compared to 2001 and all other classes decreased. Urbanization is the primary cause of the land use and land cover changes for the study area.

Keywords: Land-use/Land-cover, Coimbatore, Change detection, Remote sensing and GIS Applications
\end{abstract}

\section{INTRODUCTION}

Land use and land cover is important for many planning and management activities and is considered an essential element for modeling and understanding the earth as a system [1]. Land use/land cover of the earth surface is changing in unprecedented rates and creating major environmental concern worldwide. Understanding the land cover will help to understand the earth fundamental characteristics and processes, including productivity of the land, diversity of plant and animal species, biogeochemical and hydrological cycles [2]. The rapid growth of expansion of urban areas, population growth, transportation development, land demand, technology changes are the major driving factor of Land use and land cover changes in the world [3]. Studying, assessing and monitoring land cover changes are very important to understand environmental changes and its consequences. Land cover and land use changes may have positive or negative effects on human well-being and can also have intended or unintended consequences [4].

Remote sensing and GIS have been widely applied to understand the land use/land cover changes and are considered to be powerful to identify the temporal changes of the land surface [5]. With the recent advancement in remote sensing, geographic information system, computer technology and programming languages. It is possible to assess and monitor land-use/land-cover at different spatial and multitemporal levels [6].

\section{STUDY AREA}

Coimbatore North Taluk covers an area of $479.5 \mathrm{~km} 2$ and located between latitude $76^{\circ} 44^{\prime} 21^{\prime \prime} \mathrm{N}$ to $77^{\circ} 10^{\prime} 27^{\prime} ' \mathrm{~N}$ and longitude $10^{0} 57^{\prime} 13 \mathrm{E}$ to $11^{0} 14^{\prime} 05^{\prime}$ ' $\mathrm{E}$. The taluk boundaries Mettupalayam taluk in north, Annur and Sulur taluk in east, Coimbatore South taluk and Noyyal river in south and Western Ghats mountain range on the west (Figure 1).

The study area lies in the rain shadow region of Western Ghats and experiences a pleasant climate most all the years around. In the district, the maximum temperature is recorded in the month of April and minimum temperature is recorded in the month of December. In 2009-10, the maximum temperature of the district was $38.0^{\circ} \mathrm{C}$ and the minimum temperature was $17.4^{\circ} \mathrm{C}$.According 2011 census, the study area includes 26 revenue villages.

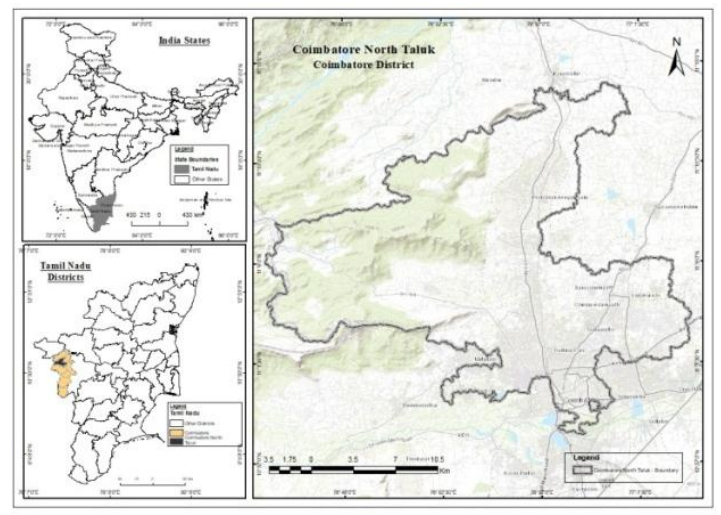

Fig. 1 Study Area Coimbatore North Taluk

\section{RESEARCH DESIGN}

The flowchart in Fig. 2 depicts the high-level methodology adopted for the present study.

\section{A. Data collection}

The study area boundary was extracted from the survey of India (SOI) toposheets serious of 1:25000 scales. Landsat and Sentinel-2A satellite images were collected from USGS Earth Explorer for the period of 2001 and 2018 respectively. In addition to the above data, various ancillary data are also collected and used as collateral data for this study. Global Positioning System (GPS) was used to collect reference points from different land use land cover categories. 


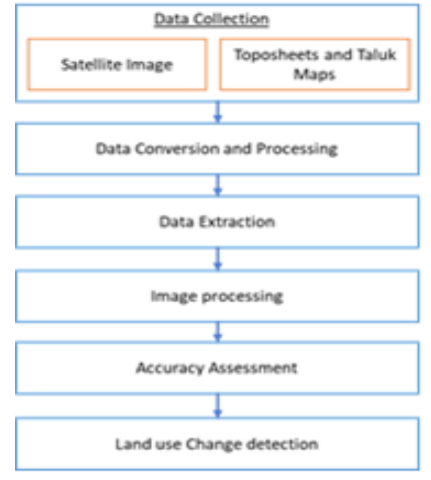

Fig. 2 Flow chart

\section{B. Pre-Processing}

Pre-processing of satellite images prior to actual change detection is an important process and has a primary unique objective of establishing a more direct relationship between the acquired data and biophysical phenomena [7]. Using ERDAS and ArcGIS applications, data are preprocessed for geo-referencing, composite bands, mosaicking and extracting raster image using the mask (Area of Interest). Also, Different raster functions were used to improve visualization and identify the different objects on the imagery.

\section{Image Classification}

Image classification is a procedure to categorize all pixels in an image into land cover classes or themes. Based on the image spectral reflectance or emissivity characteristics the pixels are grouped together in classes that are assumed to represent specific categories of earth features [8]. Different spectral band combinations and raster functions were used to improve the visualization of various objects in Landsat and Sentinel-2A imagery. A hybrid supervised classification approach was used to classify satellite images into land use/land cover classes. This approach is a combination of automated and manual classification techniques. Initially, the images were classified using Unsupervised classification process with 75 classes. Next, the unsupervised classified image was refined and edited using visualization and comparing with reference images. After classification, ground verification was done to improve the accuracy of land use / land cover.

\section{Accuracy Assessment}

Land use/land cover study would be complete without an accuracy assessment. It is an essential and crucial part of studying image classification and land use/land cover detection in order to understand and estimate the changes precisely [7]. In this study, accuracy assessment was done for 2001 and 2018 land use /land cover thematic maps using high-resolution satellite imagery and sample ground data.

\section{RESULTS AND DISCUSSION}

The land use/land cover categories of the study area consist of Built-up land, agriculture land, water bodies and forest land. The change detection results are carefully interpreted using visual interpretation techniques. The result of the study showed that the land use/land cover are undergoing a change from predominantly rural to urban. The percentage of changes for each category was shown in tabel.1. The study area 2001 and 2018, land use/land cover changes for the study areas was depicted in figure 2 and figure 3 respectively.

\section{A. Built-up Land}

The built-up land is composed of areas of intensive use with much of the land covered by human made physical structures. The study showed that built-up area increased from 61.30 sq.km (12.78\%) in 2001 to 140.21 sq.km (29.24\%) in 2018. The study observed that there is significant conversion from agriculture land to built-up land category (Figure 4). This is due population growth, economic development, and expansion of Coimbatore corporation boundaries.

\section{B. Agriculture Land}

Agriculture land is primarily used for forming and production of food, fiber, and other commercial and horticultural crops. This category covers irrigated croplands, unirrigated croplands, plantations, and fallow lands. The change detection analysis showed that agriculture land category is decreased from 260.81 sq.km in 2001 to 190.77 sq.km in 2018. Nearly 70 sq.km of agricultural lands are converted into built-up lands. Figure 5 shows the built-up areas difference for 2001 and 2018.

\section{Forest}

The western part of the study area covered by forest lands of the Western Ghats shown a decrease of 7 sq.km compare to 2001. The study found out that the expansion of agricultural land took place at the expenses of forest land between 2001 and 2018.

\section{Water bodies}

The study revealed that there is a slight decrease in water bodies. In 2001 the 18.51 sq.km of the area was covered by water bodies and in 2018 it is slightly decreased to 16.66 sq.km. The encroachment of water body is mainly for the purpose of built-up, industries and transportations.

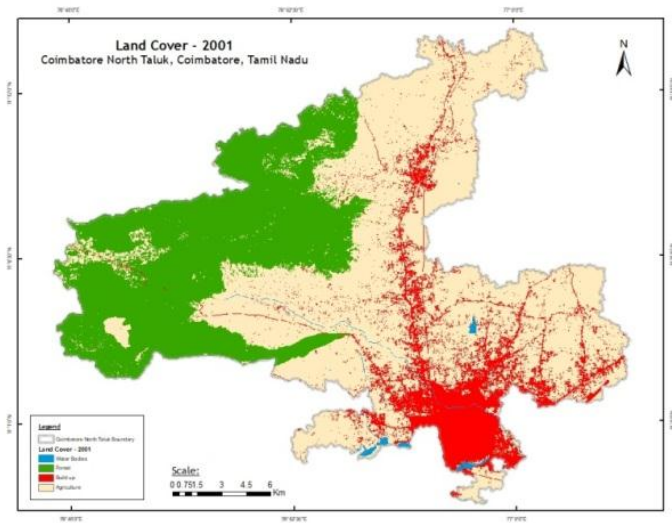

Fig. 3 Land-use/Land cover in 2001 


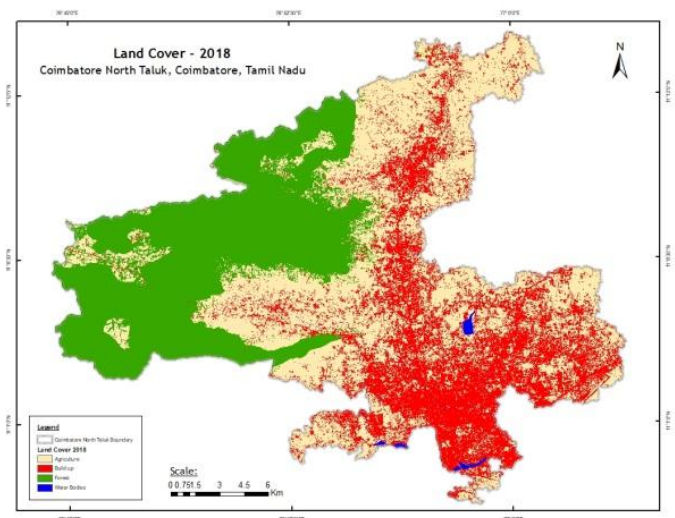

Fig. 4 Land-use/Land-Cover in 2018

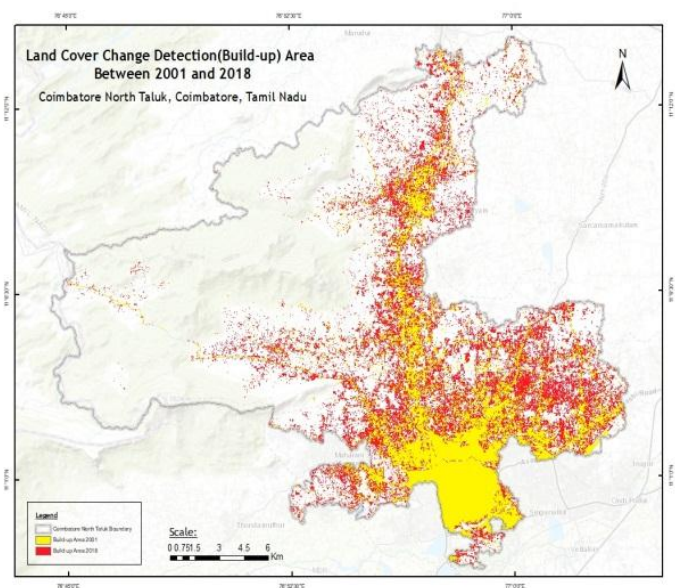

Fig. 5 Land use/Land cover Change Detection and 2018(Built-up areas) between 2001 and 2018

Land Cover Change between 2001 and 2018 (in \%)

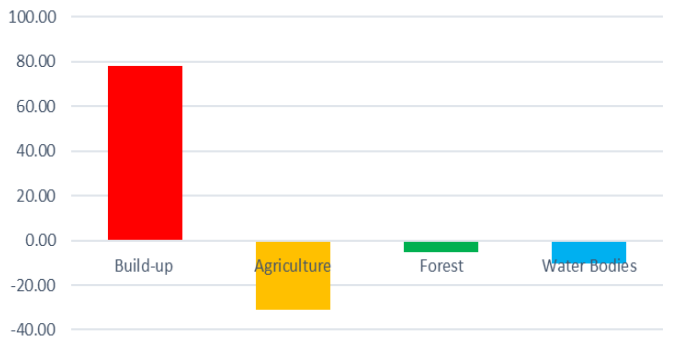

Fig. 6 Land cover change in 2001

TABLE I LAND COVER CHANGE MATRIX BETWEEN 2001 AND 2018

\begin{tabular}{|c|c|c|c|c|c|}
\hline \multirow[b]{2}{*}{ Category- } & \multicolumn{2}{|c|}{2001} & \multicolumn{2}{|c|}{2018} & \multirow{2}{*}{$\begin{array}{c}\% \\
\text { Chan } \\
\text { ge }\end{array}$} \\
\hline & $\begin{array}{c}\text { Area } \\
(\mathbf{s q . k m})\end{array}$ & $\begin{array}{c}\% \\
\text { Area }\end{array}$ & $\begin{array}{c}\text { Area } \\
(\mathbf{s q} \cdot \mathbf{k m})\end{array}$ & $\begin{array}{c}\% \\
\text { Area }\end{array}$ & \\
\hline $\begin{array}{l}\text { Built-up } \\
\text { areas }\end{array}$ & 61.30 & 12.78 & 140.21 & 29.24 & 78.31 \\
\hline $\begin{array}{l}\text { Agriculture } \\
\text { lands }\end{array}$ & 260.81 & 54.39 & 190.77 & 39.78 & -31.02 \\
\hline Forest areas & 138.89 & 28.96 & 131.87 & 27.50 & -5.19 \\
\hline $\begin{array}{l}\text { Water } \\
\text { Bodies }\end{array}$ & 18.51 & 3.86 & 16.66 & 3.48 & -10.50 \\
\hline Total & 479.51 & 100.00 & 479.51 & 100.00 & \\
\hline
\end{tabular}
changes occurred in Coimbatore North Taluk is due to urbanization process that has been observed in the last two decades. The major conversion occurred in agriculture land to built-up land category due to different anthropogenic reasons. The decrease of water bodies may be due to insufficient rainfall, non-perennial water flows in the river and encroachment. This study supports that hybrid supervised classification of temporal satellites is very useful to detect the land use/land cover changes and analyze the impact of in the ecosystem.

\section{ACKNOWLEDGEMENT}

The authors are gratefully acknowledged the support Govt Arts College, USGS, Survey of India, National Remote Sensing Center, Hyderabad, for it data products and successful completion of this study.

\section{REFERENCES}

[1] Chandra P. Giri. (2012). Remote Sensing of land use and land coverprinciples and Applications, CRC Press, 15-64.

[2] Barros, JX. (2004). Urban growth in Latin American cities: exploring urban dynamics through agent-based simulation. University of London, London, (Doctoral Thesis).

[3] DeFries, R.S. \& Belward, A.S. (2000). Global and regional land covers characterization from satellite data: An introduction to the Special Issue. International. Journal of Remote Sensing, 21, 1083-1092

[4] Hensen, M. \& DeFries, R.S. Detecting long- term global forest changes using continues fields of tree cover maps from 8-km advanced high resolution radiometer (AVHRR) data for the years 1982-99. Ecosystems, 7, 695-716.

[5] Hudak, T. \& Wessman, C. A. (1998). Textural analysis of historical aerial photography to characterize woody plant encroachment in South African Savanna, Remote Sensing of Environment, 66(3),317-330.

[6] Coppin, P., Jonckheere, I., Nackaerts, K., Muys, B. \& Lambin, E. (2004). Digital change detection methods in ecosystem monitoring: a review. Int. J. Remote Sens., 25(9),1565-1596.

[7] Ercy C Cheruto. (2016). Assesment of Land use and Land cover changes using GIS and Remote Sensing techniques: A Case study of Makueni county, Kenya. Journal of remote sensing \& GIS, 5(4), 1-6.

[8] Thomas M. Lillesand, Ralph W. Kiefer \& Jonathan W. Chipman, (2012). Remote sensing and Image interpretation: Seventh Edition, John Wiley \& Sons, Inc.

[9] Vahita, T., Muruganandham, R., Ruthervel Murthy, K., Sundararaj, P., and Kumaraswamy, K. (2012). Spatio- Temporal Evaluation of Land use/land cover changes in Noyyal river basin, Tamil Nadu, India: A case study using Geospatial techniques, Indian journal of natural Sciences. 3,1101-1103. 